\title{
DE CE ESTE EPIGENETICA IMPORTANTĂ PENTRU PEDIATRIE?
}

\author{
Prof. Dr. Sorin Buzinschi
}

Facultatea de Medicină, Universitatea Transilvania, Braşov

\begin{abstract}
REZUMAT
Înțelegerea schimbărilor de patologie din ultimele decade a devenit posibilă datorită achizițiilor epigenetice. Această ramură a geneticii explică cum influențează mediul funcționarea dinamică a genelor. Variațiile epigenetice sunt determinate de nutriție, infecții, noxe chimice, stres. Programarea metabolică inițiată din viața fetală este determinantă pentru patologia cronică a vârstei adulte. Infecțiile, bolile alergice, afecțiunile maligne, prezintă o semnificativă dimensiune epigenetică. Medicul pediatru, acționând la începutul ciclului de viață, poate interveni în derularea acestor procese prin abordarea profilactică şi prin terapia epigenetică, ultima fiind în curs de cristalizare.
\end{abstract}

Cuvinte cheie: pediatrie, epigenetică, programare, terapie

În ultimele decade, o observație elementară ne arată creşterea explozivă a frecvenței unor afecțiuni altă dată rare. Explicațiile asupra originii genetice a acestora se lovesc de constatarea că fondul genetic al populațiilor este stabil, în timp ce populaţiile prezintă modificări majore de patologie din cauza schimbărilor mediului de viață. O privire de ansamblu asupra patologiei aşează pediatria la începutul unui lanț de modificări care se amplifică de-a lungul vieții. Înțelegerea globală a patologiei vârstelor este îngreunată de diviziunea profesiei medicale între ramurile sale, decurgând din cantitatea uriaşă de informație a fiecărei specialități, fiecare cu un teritoriu bine delimitat şi fără interferențe (deseori) cu alte discipline. Abordarea epigenetică estompează hotarele formale trasate de segmentarea pe specialități şi pe vârste, pornind de la realitatea unei continuități biologice din etapa embrionară şi până la moarte. Pentru percepția adecvată a dinamicii funcționării genelor, considerăm necesară includerea unui glosar de termeni epigenetici (1).

\section{Epigenetica}

Parte a geneticii care studiază modificările trăsăturilor fenotipice induse de mediu prin modificarea reversibilă a funcțiilor genelor, fără modificarea secvențelor ADN. Reglarea epigenetică este mediată de metilarea ADN, modificări fizice ale structu- rii cromatinei şi de acțiunea moleculelor de ARN necodante.

\section{Cromatina}

Complex format de ADN şi histone care compun cromozomii. Cromatina condensată (heterocromatina), în care ADN şi histonele sunt strâns împachetate, blochează accesul factorilor transcripționali la expresia genelor. Forma de cromatină deschisă permite factorilor transcriptionali să acceseze ADN şi să iniţieze transcripția.

\section{Metilarea ADN}

Fixarea grupului metil în poziția 5 a inelului citozin-pirimidinei (C) din structura citozin-guanină dinucleotidică $(\mathrm{CpG})$, reacție catalizată de $\mathrm{ADN}$ metiltransferaze (DNMTs). Metilarea ADN este un proces epigenetic determinant pentru represia transcripției prin sistarea ataşării factorilor transcripționali.

\section{Modificările histonelor}

$\mathrm{Au}$ loc în zone specifice prin acetilare, metilare şi alte procese. Ele modulează expresia genelor prin schimbarea structurii cromatinei. Ca şi metilarea $\mathrm{ADN}$, modificările histonelor sunt dinamice şi reglate activ de enzimele catalitice ale gazdei. 


\section{Imprinting genomic}

Proces epigenetic prin care este exprimată doar o singură alelă provenind de la unul din părinți. Este un proces fundamental pentru creştere şi dezvoltare.

\section{Moştenirea epigenetică}

În majoritate, informația genetică se transmite de la părinți la copii prin codul genetic, însă unele trăsături epigenetice se mențin şi trec de la o generație la alta.

\section{Alele}

Genele sunt localizate pe cromozomi, fiecare genă ocupând un locus. În loci situaţi în aceeaşi po- ziție pe perechea de cromozomi omologi pot fi versiuni identice ale genei (organism homozigot) sau secvențe de ADN diferite-alele (organism heterozigot) (Fig. 1).

Modul în care genele se exprimă în mod diferit, fără modificarea secvențelor $\mathrm{ADN}$, este determinat de schimbările funcționale ale acestora prin metilarea $\mathrm{ADN}$, modificările histonelor şi ale microARN, fondul genetic fiind considerat partea de „hard“, iar epigenetica „softul“. Factorii epigenetici sunt o formă de memorie celulară dobândită că răspuns la variaţiile mediului şi pot influenţa modul şi timpul de exprimare al genelor printr-un mecanism aparent simplu de tip ,închis“, „,deschis“. La întrebarea enunțată în titlu pot fi formulate 3 răspunsuri principale:

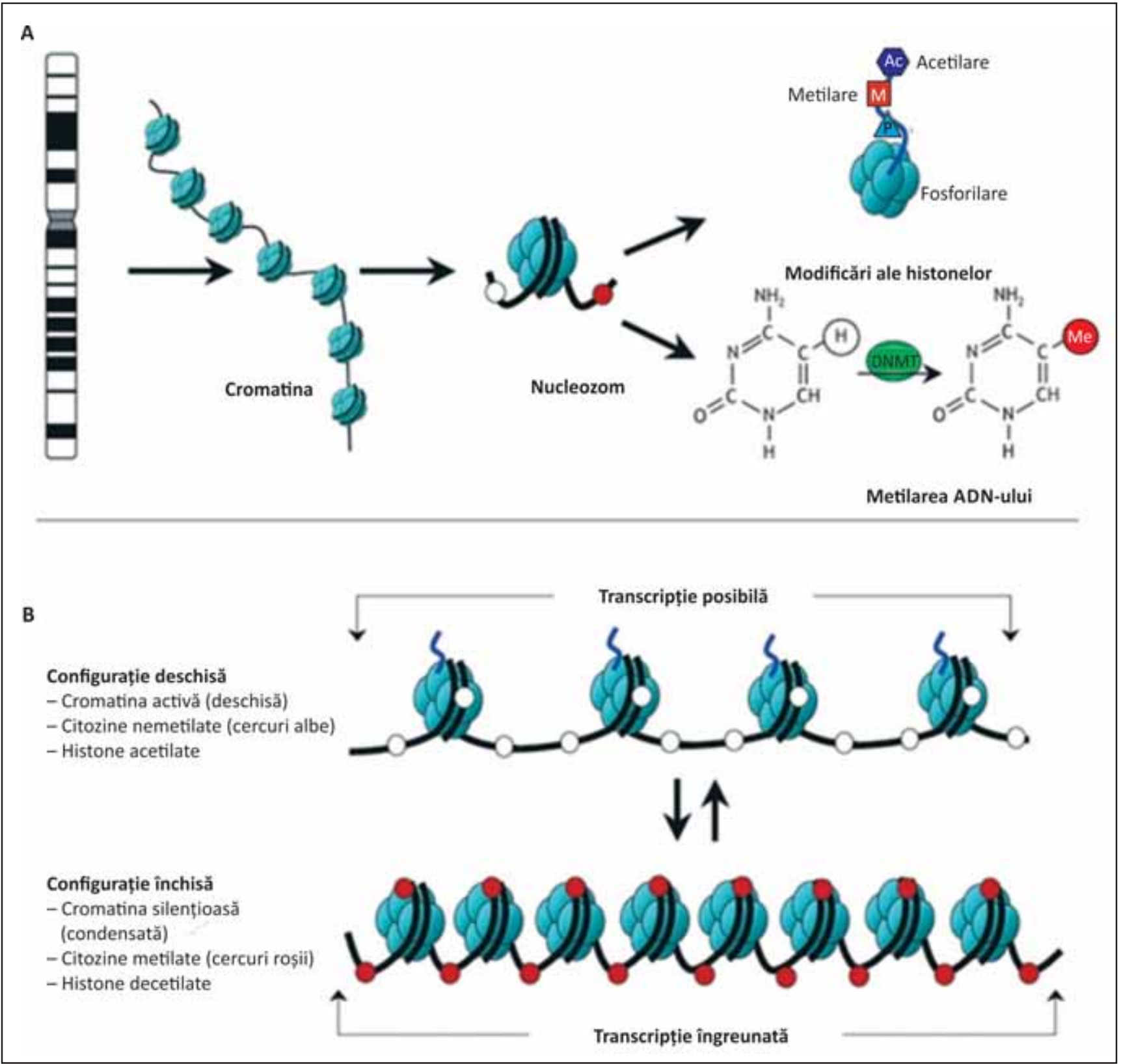

FIGURA 1. Modificările epigenetice ale ADN. Modificat după Rodenhiser şi Mann 2006 (2) 
1. Pentru că pune în prim plan importanța dezvoltării fetale şi a copilăriei la originea unor afecțiuni care se manifestă la maturitate şi bătrânețe;

2. Pentru că argumentează că unele din trăsăturile părinţilor se transmit la descendenți prin memoria gameților, fără modificări ale secvențelor ADN;

3. Pentru că pune în evidență restructurarea permanentă a funcționarii celulare şi modul în care influenţele din mediu (nutriţionale, toxice, stil de viață) îşi pun amprenta asupra patologiei.

În ultimii ani, cercetarea genetică (vezi GWAS genome-wide association studies) a identificat gene sau variante genetice care stau la baza unor boli cu transmisie complexă. Evoluția studiilor GWAS privind rolul factorilor genetici în dezvoltarea unor boli s-a bazat pe asocierea dintre variațiile genomice şi corespondentul lor fenotipic din populație. Ipoteza „boli comune, variante comune“ postulează că bolile comune ale adultului pot fi atribuite unor variante alelice comune de risc, identificabile la cel puțin $1-5 \%$ din populație. $\mathrm{Cu}$ toate acestea, caracterul înnăscut al bolilor complexe ale adultului nu a putut fi demonstrat decât în proporție relativ redusă $(25 \%)$. Rolul determinant al unor variante genetice în obezitatea comună, ateroscleroza, diabetul zaharat de tip 2 nu este susţinut convingător de date statistice, de aceea schimbarea paradigmei asupa patogeniei acestor boli a impus o componentă nouă, cea epigenetică. Poate epigenetica, un domeniu nou al geneticii să ofere explicații asupra unor afecțiuni care încep din viață intrauterină şi se manifestă în viaţă adultă? Poate fi pediatria un domeniu cheie în găsirea soluţiilor la dezvoltarea epidemică a unor afecțiuni în epoca modernă?

Epigenetica explică modul în care zigotul care se dezvoltă în peste 220 de tipuri de celule cu acelaşi ADN se diferenţiază în celule şi organe cu structură şi funcții diferite. Pentru majoritatea autorilor, termenul de epigenetică se referă la moştenirea epigenetică, adică la transmiterea de la o generație la alta de modificări în expresia genelor, declanşate de stimuli diferiţi. Variațiile epigenetice sunt manifeste în toate perioadele de viață, fiind modulatori permanenți de răspuns la toxice din mediu, infecții, modificări ale aportului nutriţional, noxe cancerigene, interacțiuni socio-emoționale (3). Vom prezența câteva din zonele de patologie în care modificările epigenetice sunt pe prim plan. Infecțiile acute şi cronice, bolile alergice, afecțiunile maligne şi bolile metabolice ale adultului prezintă o semnificativă dimensiune epigenetică. Afecțiunile din grupele citate în care epigenetica contribuie la descifrarea mecanismelor patogenetice pot beneficia de noi terapii, unele deja în curs de aplicare.

\section{Modificări epigenetice produse de infecțiile bacteriene şi virale}

Germenii patogeni se adaptează gazdelor lor şi au capacitatea de a interfera în procesele celulare şi tisulare, într-un război de la celulă la celulă, după depăşirea sistemelor immune de apărare. Manipularea microbiană a mecanismelor epigenetice, din partea paraziților intracelulari, le-a permis acestora să dezvolte numeroase căi de a sustrage substraturi pentru completarea ciclului lor de viață şi pentru a evita răspunsurile immune ale gazdei (4-6).Infecția cu Helicobacter pylori (Hp) declanşează un proces inflamator care poate duce la gastrită cronică, ulcer gastric sau duodenal. Inflamaţia cronică este urmată de modificări ale mucoasei şi uneori malignizare. Factorii de virulenţă ai Hp sunt citotoxina VacA şi CagA. Oncoproteina CagA acționează în celulele epiteliului gastric şi induce proliferare celulară necontrolată şi instabilitate cromozomială. Modificările epigenetice legate de carcinogeneză cuprind atât hipometilare genomică globală, cât şi arii hipermetilate care includ genele supresoare tumorale (4). Mycobacterium tuberculosis şi alți patogeni intracelulari au dezvoltat numeroase mecanisme epigenetice care inhibă secreția de IFN- $\gamma$ şi transcripția genelor legate de imunitate. Unele specii bacteriene, între care cităm Shigella flexneri, Escherichia coli, Chlamidia pneumoniae sunt capabile să producă modificări epigenetice în celulele umane. Virusurile hepatitice, prin moleculele lor efectoare, dereglează progresia ciclului de multiplicare celulară, iar prin oncoproteinele lor produc hipometilare globală a $\mathrm{ADN}$, fenomen larg răspândit în celulele neoplazice. Carcinoamele hepatocelulare de diferite etiologii virale se caracterizează printr-o ,semnătură“ epigenetică unică, specific virală (4).

\section{Modificări epigenetice în bolile alergice}

Creşterea alarmantă a incidenței unor boli alergice că astmul, rinita alergică şi eczema a fost legată de modificările mediului şi stilului de viață, sugerând că funcționarea sistemului imun este influențată semnificativ de acestea. Deşi componenta genetică a astmului apare evidentă în studiile epidemiologice, până acum nu au fost puse în evidență gene specifice sau cele propuse au fost variabile în masa populațiilor. Recent, prin GWAS (GenomeWide Association Studies), a fost posibilă identificarea unor gene implicate în răspunsul imun înnăscut şi adaptativ (7). Aportul mecanismelor epigenetice în bolile alergice a fost demonstrat în studii experimentale şi clinice. Ele vizează perioada de viaţă fetală, semnificativă pentru dezvoltarea imună, diferențele de expresie ale unor gene în bolile 
alergice, reglarea epigenetică a dezvoltării imune şi factorii care modulează riscul alergic pe cale epigenetică.

Studii asupra unor bolnavi astmatici şi pe gemeni monozigoți discordanți pentru astm pun în lumină metilarea aberantă a ADN şi modificările histonelor, cu programarea răspunsurilor celulelor T şi a altor parametri imuni încă din viață intrauterină (8-10). Aceste modificări vor determina riscul pentru astm şi severitatea acestei afecțiuni în perioadele ulterioare de viaţă. Deşi există o legătură puternică între fondul genetic şi astm un studiu asupra gemenilor monozigoți discordanți pentru astm a arătat diferențe semnificative ale modificărilor epigenetice (metilarea ADN) ale celulelor T pentru cei afectați față de gemenii nonastmatici (11) (Fig. 2).

\section{Programarea metabolică la copil}

Primele indicii că mediul intrauterin în care se dezvoltă fătul are o influență importantă asupra stării de sănătate şi supraviețuire datează din anii 90.
S-au stabilit corelații între greutatea mică la naştere şi evoluția ulterioară către obezitate, HTA, diabet zaharat de tip 2, boli cardiovasculare (12).

Numeroase studii care au implicat zeci de mii de subiecți au ajuns la concluzia că lipsurile nutriționale din perioada sarcinii sau noxe acționând asupra fătului în perioade critice de dezvoltare au ca rezultat formarea unui fenotip economic (adică programat să consume puțin). Născuți prematur, mici pentru vârsta gestațională, sau numai afectați de restricțiile alimentare materne din cursul sarcinei, aceşti copii vor dezvolta ulterior (uneori din perioada de adolescență) bolile metabolice ce definesc patologia adultului sau a perioadei de bătrânețe. Sub nume ca teoria originii fetale (13), răspunsul adaptativ predictiv $(14,15)$ sau originea stării de sănătate şi de boală în perioada de dezvoltare $(16,17)$, sunt cumulate date experimentale, epidemiologice şi clinice, care urmăresc etapele de instalare a patologiei metabolice a adultului şi substratul molecular al acestor modificări. Un exemplu su-
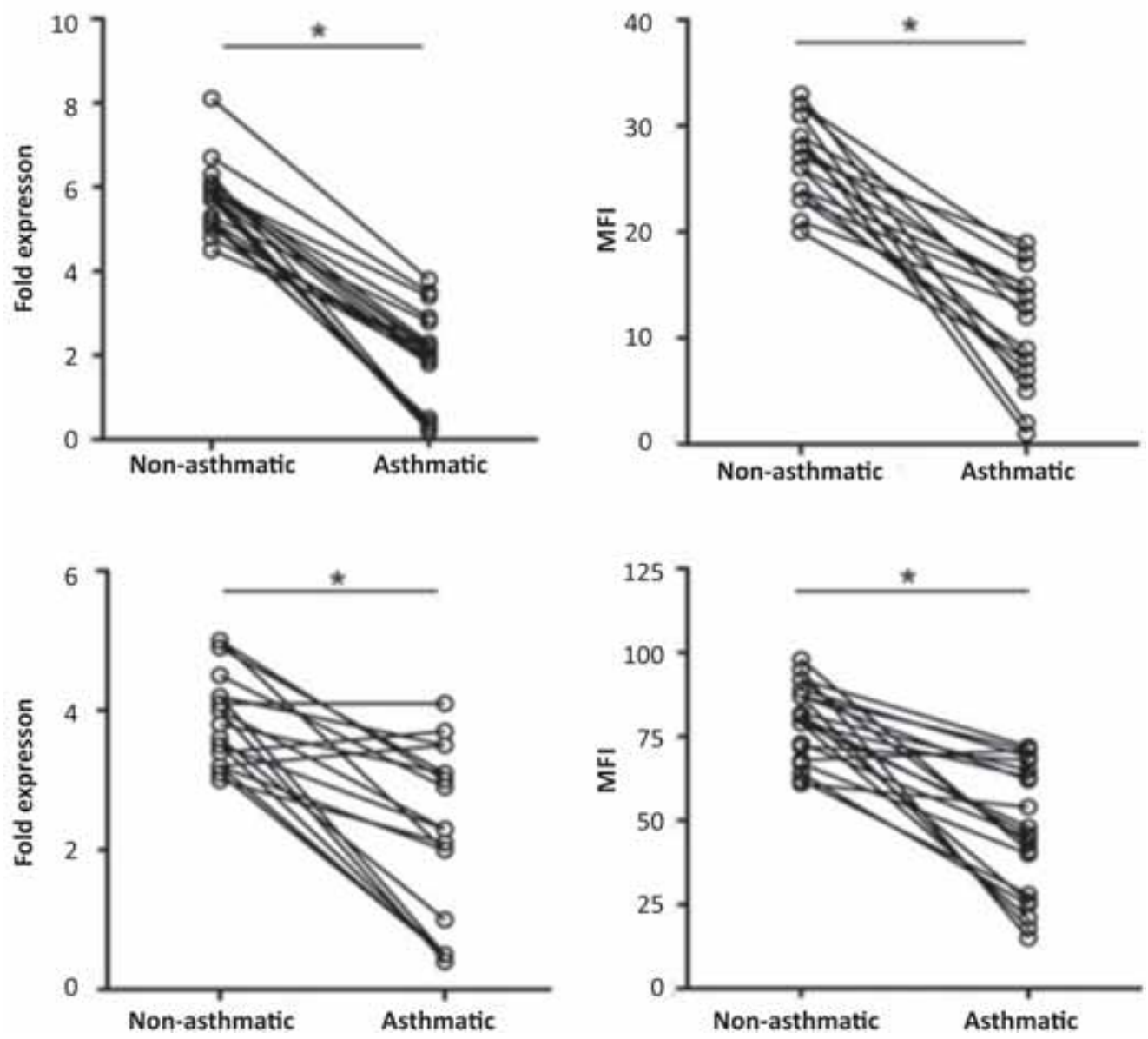

FIGURA 2. Scăderea expresiei proteinelor implicate în funcția celulelor T efectoare (Teff) şi T reglatoare (Treg) la gemeni monozigoți discordanți pentru astm. A) Expresia FOXP3 (proteină implicată în răspunsul imun, reglează dezvoltarea/funcția celulelor Treg); B) Nivelul proteinei FOXP3 extrasă din celulele Treg; C) Expresia genei IFN- $y$; D) Nivelul proteinei IFN- $y$ extrasă din celulele Teff. După Runyon et al, 2012 (9) 
gestiv al efectelor tardive ale malnutriției de sarcină 1-a constituit perioada de foamete din Olanda din cursul celui de-al 2-lea Război Mondial, când efectele carentelor de nutriție fetală au fost evidente în patologia adulților, 50 de ani mai târziu (18) (Fig. 3).

Implicațiile malnutriției intrauterine au o semnificație majoră asupa patologiei din largi zone geografice.Yajnick şi col (19), având în vedere că nou născuții din India sunt în medie mai mici decât cei europeni, au arătat că adipozitatea şi hiperinsulinemia lor este prezentă la naştere. Comparativ, un grup de 157 de nou-născuți din India cu greutatea medie de $2.800 \mathrm{~g}$, față de $3.475 \mathrm{~g}$ în Anglia, aveau concentrații ale insulinei în cordonul ombilical mai ridicate decât grupul martor (34,7 pmol/1 VS 20,8 pmol/l). Wang et al. (20) au urmărit o cohortă de copii, unii născuți la termen şi alții cu diferite grade de prematuritate. Nivelurile insulinei plasmatice au fost de 2 ori mai mari la născuții cu prematuritate avansată față de cei născuți la termen şi s-au menținut ridicate şi ulterior.

Paradoxal, copiii macrosomi, sau născuții din mame diabetice au o traiectorie de patologie convergentă cu cea a copiilor născuți prematuri sau „mici pentru dată“", prin creşterea insulinei plasmatice, obezitate şi boală metabolică ca adolescenți şi adulți. Marceau şi col (21) au comparat greutatea copiilor născuți înainte de chirurgia bariatrică maternă la 783 de femei obeze cu alți copii născuți de femei care au traversat acelaşi tip de operație. Dintre cei 166 de copii născuți postchirurgie, numai $7,7 \%$ au avut macrosomie fetală comparativ cu $34,8 \%$ în grupul matern care nu au trecut prin această manevră chirurgicală.

Aceste date arată cât de importantă este oferta metabolică maternă pentru metabolismul fetal şi efectele ei asupra următoarei generații, fără inter- venția unor factori genetici. Modificările metabolismului matern şi fetal contribuie la programarea dezvoltării intrauterine; acest program structurează funcţionarea organismului şi în perioadele ulterioare de viață. Ținând cont de ritmul de creştere al obezității la copiii din țară noastră, ne putem aştepta la efecte negative asupra generațiilor viitoare.

\section{Modificări epigenetice în tulburările com- portamentale şi afecțiunile psihiatrice}

Intervenția proceselor epigenetice în procesele psihice este condiționată de factori familiali, sociali şi de mediu. Cercetări experimentale au arătat că animalele nou-născute atent îngrijite de mamele lor în prima săptămână de viaţă prezintă modificări ale expresiei genelor la nivel cortical şi răspunsuri scăzute la stres. Aceste răspunsuri durabile sunt diferite de cele ale puilor neglijați, care vor reacționa disproporționat la factorii agresivi din mediu. Modificări similare fost evidențiate la copiii supuşi neglijenței şi abuzurilor, datorate modificărilor epigenetice ale receptorului pentru glucocorticoizi din hipocamp (22).

Semnalele din mediul social contribuie la remodelarea continuă a funcțiilor neuronale prin intermediul aparatului epigenetic, proceselor de metilare ale ADN şi configuraţiei cromatinei, fiind active şi dinamice în cursul vieții (23). Spre deosebire de mutațiile genetice, memoria celulară indusă epigenetic este reversibilă, aşa cum arată evoluția modificărilor de tip obsesiv/compulsiv, a depresiei sau a atacurilor de panică (24). Pentru aceştia din urmă, modificarea contextului afectiv, terapia comportamentală cognitivă şi exercițiile fizice contribuie la modificarea stării de metilare a unor gene [ex. monoaminooxidaza A (MAOA) şi la expresia diferită a acestora] (25).
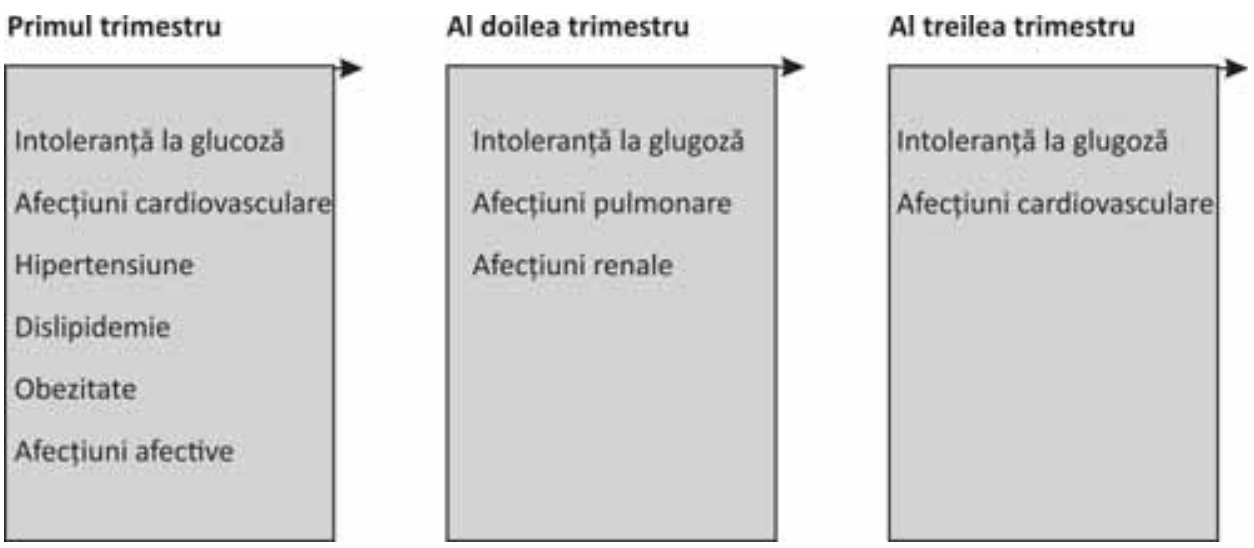

FIGURA 3. Structura patologiei adulților de peste 50 de ani în funcție de perioada de malnutriție intrauterină din cursul sarcinei, Olanda 1944-1945. După Boekelheide et al. 2012 (18). 


\section{Transmiterea epigenetică transgenerațională}

Instalarea de elemente ale sindromului metabolic, ca obezitatea şi DZ 2 pot fi efecte aditive în interval de mai multe generații (26). Studii asupra unor familii din Suedia pentru mai mult de 100 de ani au pus în evidență că bărbații care au avut acces larg la produse alimentare în perioada prepubertară au avut nepoți cu risc ridicat de deces prin DZ 2. Alte studii au arătat că mortalitatea prin diabet şi boli cardiovasculare a fost influențată de starea nutrițională a părinților şi bunicilor. Aceste studii sprijină idea că există o memorie a mediului de viață transmisă prin gameți şi reflectată în tulburările metabolice ale urmaşilor $(27,28)$. S-a considerat mult timp că modificările epigenetice din cursul vieții sunt şterse în cursul gametogenezei, adică spermatozoidul şi ovulul nu vor purta experiența epigenetică dobândită de genitori. Cu toate acestea, datele actuale evidențiază că markerii epigenetici nu sunt în întregime înlăturați la pasajul dintre generații şi că elemente din existența predecesorilor pot trece la copii, nepoți şi urmaşii lor. Moştenirea epigenetică transgenerațională are ca rezultat formarea unor fenotipuri în generații succesive, ca rezultat al modificărilor epigenetice transmise prin gameți (28). Conservarea datelor oferite de mediu poate fi un mecanism de adaptare funcțional, dar şi sursă de tulburări metabolice. Unele din numeroasele exemple de transmisie epigenetică vin din cercetarea experimentală în care dezechilibre nutriționale din prima generație sunt sursă de obezitate, rezistență la insulină, DZ 2 şi ateroscleroză pentru generațiile următoare (29-31). Moştenirea epigenetică transgeneraţională şterge demarcația dintre transmiterea bazată pe secvențele ADN şi cea epigenetica şi, deşi încă o noțiune controversată, schimbă concepția că bolile cronice complexe sunt în întregime de origine genetică (31-33). Destinația finală a acestor cercetări o reprezintă politicile de sănătate publică, care trebuie să facă față unui val de schimbări rapide în starea de nutriţie şi de patologie în diferite colțuri ale lumii (34).

\section{Surse de informare epigenetică pentru medicul practician}

În absenţa unor investigații larg utilizabile asupra markerilor epigenetici, este utilă cunoaşterea unor factori parentali posibil implicați în patologia epigenetică. Principalii factori materni legați de patologia epigenetica sunt: greutatea (BMI), creştere ponderală excesivă în sarcină, vârstă, fumat, restricții alimentare/exces, diabet, HTA, preeclampsie, astm, boli alergice, stres psihosocial, depresie, traume, expunere profesională/de mediu la chimicale (35). O serie de factori cu efecte asupra patologiei din perioada adultă pot fi identificați cu uşurință din perioada neonatală. Dintre aceştia, menționăm ca elemente de alertă: greutatea pentru vârstă gestațională (mic pentru dată), prematuritate, macrosomie, toxice identificate în perioada prenatală (35). Abordarea profilactică, cea mai necostisitoare terapie, este larg accesibilă. Este oare posibil ca schimbarea dietei şi eliminarea excesului ponderal al viitoarelor mame să influențeze pe termen lung fenotipul şi sănătatea copiilor? Studiile clinice au arătat că după diminuarea drastică a obezităţii prin chirurgia bariatrică a avut loc reprogramarea metabolică maternă şi scăderea obezității copiilor. În plan populațional, combaterea obezității s-a dovedit un eşec. Pentru realizarea unui echilibru nutriţional, s-au propus o serie de obiective, dintre care menționăm:

1. Abordarea nutrițională a femeilor din perioada periconcepțională prin educație sanitară pentru promovarea stării de sănătate fetală;

2. Încurajarea alimentației naturale;

3. Introducerea în programa şcolară de noțiuni elementare despre nutriția corectă şi importanța ei;

4. Încadrarea largă în sistemul educațional a sportului şi exercițiilor fizice;

5. Dezvoltarea unor politici guvernamentale pentru protecția consumatorilor față de punerea în consum a unor produse cu conținut crescut de grăsimi, hidrați de carbon şi sare prin avertizare, etichetare diferenţiată şi informare permanentă. Este important faptul că flexibilitatea epigenetică permite organismului să se adapteze rapid la fluctuațiile mediului şi că acest proces dinamic poate fi influențat.

\section{Terapia epigenetică}

Unele nutrimente sau suplimente alimentare au impact biologic prin intervenţia lor în refacerea echilibrului epigenetic. Au fost sugerate efectele polifenolilor din dietă, conținuți în ceaiul verde şi vinul roşu, pentru activitatea lor antitumorală (Tabelul 1). Promisiunea cea mai semnificativă a terapiei epigenetice este legată de boala canceroasă. S-a considerat că instalarea cancerului este provocată de acumularea defectelor genetice prin mutații, deleții, procese de translocare, care permit dezvoltarea şi proliferarea celulelor maligne. Alături de acestea, au fost evidențiate dereglări epigenetice prin metilarea ADN, modificările histonelor şi ale microARN, cu exprimarea genelor care transformă celulele normale în celule maligne (3). Spre deosebire de mutațiile genetice, modificările epigenetice 
TABELUL 1. Nutrimente/suplimente nutriționale cu efecte epigenetice. Preluat parțial după Szyc et al, 2015 (36)

\begin{tabular}{|l|l|}
\hline Cadru nutrițional & Efectori \\
\hline Donori de grupări metil & $\begin{array}{l}\text { Folat, colină, vitamina B12. } \\
\text { metionină, betaină, serină, glicină }\end{array}$ \\
\hline Acizi grași & DHA, EPA, ARA, butirat \\
\hline Vitamine & $\begin{array}{l}\text { Vitamina D, vitamina C, retinol, } \\
\text { tocoferoli }\end{array}$ \\
\hline Fitoderivați & $\begin{array}{l}\text { Resveratrol, curcumin, polifenoli, } \\
\text { genistein, izoflavone din soia }\end{array}$ \\
\hline
\end{tabular}

sunt reversibile şi pot reactiva sistemele celulare antitumorale sau inhiba transcripția oncogenelor. În baza acestui concept, se dezvoltă noi strategii terapeutice, unele în curs de cristalizare. Nutriția în toate etapele de viață, stresul, activitatea fizică, fumatul, alcoolul, infecțiile pot destabiliza markerii epigenetici, favorizând bolile metabolice şi cancerul. Principiile epigenetice de sanogeneză trebuie aplicate în practică încă din sarcină şi urmărite de-a lungul copilăriei, ca premiză pentru o bună stare de sănătate ulterior. Departe de a fi o descoperire în căutarea unor aplicații, epigenetica reprezintă o mare şansă de ameliorare a paradigmelor medicale. 